\title{
PENYULUHAN BERBASIS MULTIMEDIA TENTANG MASALAH PENYALAGUNAAN MINUMAN KERAS DAN OPTIMALISASI KEGIATAN ORGANISASI SISWA SMK LIKUPANG
}

\author{
Sam Julius Richard Saroinsong \\ Fakultas Ilmu Sosial \\ samsaroinsong@yahoo.com
}

\begin{abstract}
ABSTRAK
Kegiatan pengabdian kepada masyarakat ini bertujuan untuk Memberikan pengetahuan tentang bahaya dan sanksi hukum penyalahgunaan minuman keras bagi siswa-siswa dan guru-guru di SMK Likupang, Mengoptimalkan kegiatan organisasi Siswa SMK Likupang serta Membentuk wadah/organisasi siswa anti miras dan Pembentukan kelompok-kelompok belajar di luar sekolah. Metode yang digunakan dalam kegiatan ini yaitu Metode Penyuluhan melalui multimedia, media cetak seperti brosur-brosur dan selebaran yang berisi anti miras serta metode diskusi dan pembentukan wadah/organisasi siswa anti miras.
\end{abstract}

Kata kunci : Minuman keras, siswa, Undang-Undang Miras

\section{PENDAHULUAN}

Masa remaja secara psikologi merupakan masa peralihan dari masa anak-anak ke masa dewasa, pada masa remaja terjadi kematangan secara kognitif yaitu interaksi dari struktur otak yang telah sempurna dan lingkungan sosial yang semakin luas yang memugkinkan remaja untuk berfikir abstrak. Pada usia remaja inilah berkembang sifat, sikap dan perilaku yang selalu ingin tahu, ingin merasakan dan ingin mencoba. Tentu apabila tidak segera difasilitasi atau diarahkan bukan tidak mungkin akan salah arah dan berdampak negatif (Komalasari dalam Hutagalung C, 2008 : 1).

Fase remaja merupakan segmen perkembangan individu yang sangat penting, yang diawali matangnya organ-organ fisik (seksual) sehingga mampu bereproduksi. Menurut Knopka dalam Yusuf (2007 : 184) masa remaja ini meliputi (a) remaja awal: 12-15 tahun; (b) remaja madya: 15-18 tahun, dan (c) remaja akhir: 19-22 tahun. Sementara Slazman mengemukakan, bahwa remaja merupakan masa perkembangan sikap tergantung (dependence) terhadap orangtua kearah kemandirian (independence), minatminat seksual, perenungan diri, dan perhatian dan nilai-nilai estetika dan isu-isu moral.

Remaja bukan sebagai periode konsolidasi kepribadian, tetapi sebagai tahapan penting dalam siklus kehidupan. Masa remaja berkaitan erat dengan perkembangan "sence of identity vs role confusion", yaitu perasaan atau kesadran 
akan jati dirinya. Remaja dihadapkan pada berbagai pertanyaan yang menyangkut keberadaan dirinya (siapa saya), masa depanya (akan menjadi apa saya?), peran-peran sosialnya (apa peran saya dalam keluarga saya dan masyarakat, dan kehidupan beragama; kenapa harus beragama?) (Yusuf, 2007 : 188). Apabila remaja berhasil dalam memahami dirinya, peran-peranya, dan makan hidup beragama, maka ia akan menemukan jati dirinya, dalam artian dia akan memiliki kepribadian yang sehat. Sebaliknya apabila gagal, maka dia akan mengalami kebingungan atau kekacauan (confusion). Suasana kebingungan ini akan berdampak kurang baik bagi remaja. Dia cenderung kurang dapat menyesuaikan dirinya, baik terhadap dirinya maupun orang lain (Yusuf, 2007 : 188).

Masa remaja dikenal sebagai masa yang penuh kesukaran. Bukan saja kesukaran bagi individu yang bersangkutan, tetapi juga bagi orang tuanya, masyarakat bahkan sering kali aparat keamanan. Hal ini disebabkan masa remaja merupakan masa transisi antara masa kanakkanak dan masa dewasa. Masa transisi ini seringkali menghadapkan individu yang bersangkutan kepada situasi yang membingungkan, disatu pihak ia masi anakanak, tetapi dilain pihak ia harus bertingkah laku seperti orang dewasa. Situasi-situasi yang menimbulkan konflik seperti ini, seringkali menyebabkan perilaku-perilaku aneh, canggung dan kalau tidak kontrol bisa menjadi kenakalan (Purwanto, 1999 : 29).

Remaja sebagai individu sedang berada dalam proses berkembang atau menjadi (becoming), yaitu berkembang kearah kematangan atau kemandirian. Untuk mencapai kematangan tersebut, remaja memerlukan bimbingan karena mereka masih kurang memiliki pemahaman atau wawasan tentang dirinya dan lingkungannya, juga pengalaman dalam menentukan arah kehidupannya. Proses perkembangan individu tidak selalu berjalan secara mulus atau sesuai harapan dan nilai nilai yang dianut, karena banyak faktor yang menghambatnya. Faktor penghambat ini bisa bersifat internal atau eksternal. Faktor eksternal adalah yang berasal dari lingkungan seperti ketidak stabilan dalam kehidupan sosial politik, krisis ekonomi, perceraian orang tua, sikap dan perlakuan orang tua yang otoriter atau kurang memberikan kasih sayang dan pelecehan nilai nilai moral atau agama dalam kehidupan agama atau masyarakat(Yusuf, 2007 : 209 - 210).

Iklim lingkungan yang tidak sehat tersebut, cenderung memberikan dampak yang kurang baik bagi perkembangan remaja dan sangat mungkin mereka akan mengalami kehidupan yang tidak nyaman, stres atau depresi. Dalam 
kondisi seperti inilah, banyak remaja yang meresponnya dengan sikap dan perilaku yang kurang wajar dan bahkan amoral, sperti kriminalitas, meminum minuman keras, penyalahgunaan obat terlarang, tauran dan pergaulan bebas (Yusuf, 2007 : 210).

Masa remaja dalam kehidupan sehari -hari sangat berkaitan erat dengan aspek psikologi yang menjadikan remaja sering mancoba sesuatu untuk alasan mencari jati diri. Kadang remaja salah mengartikan jati diri sehingga terjebak dalam pergaulan bebas terutama terjebak dalam hal penggunaan minuman keras, selain faktor rasa ingin mencoba, faktor lingkungan atau pergaulan juga dapat mempengaruhi keingintahuan remaja tentang minuman keras, jadi pengaruh perubahan psikologi dapak berdampak pada penggunaan minuman keras pada masa remaja.

Pada saat sekarang banyak remaja yang mengatakan bahwa dengan minum minuman keras kepercayaan diri mereka bertambah dari yang pemalu menjadi pemberani, mereka beranggapan bahwa semua masalah dapat teratasi dengan minum minuman keras, minuman keras dapat memperbanyak teman. Tapi sesuai kenyataan minuman keras dapat merusak proses berfikir dan menjadikan seorang tidak sadarkan diri atau bertindak tidak sesuai kehendak yang dapat berujung pada tindak perilaku kriminal seperti mencuri, tawuran, pelecehan sexual, sex bebas dan lain sebagainya Berdasarkan obervasi awal yang telah dilakukan di Sekolah Menengah Kejuruan (SMK) Likupang Kabupaten Minahasa Utara yang memiliki 304 siswa bahwa sebagian siswa terlebih yang laki-laki pernah meminum minuman keras bahkan ada yang sampai hilang kendali/mabuk walaupun sampai saat ini belum ada siswa yang terlibat perbuatan kriminal. Lebih lajut dari hasil wawancara ternyata banyak yang belum mengetahui tentang bahaya dan sanksi hukum dari penyalahgunaan minuman keras. Salah satu faktor yang menyebabkan siswa mencoba minuman keras diantaranya faktor lingkungan pergaulan baik pada saat di sekolah maupun di luar sekolah, dimana kurangnya pengetahuan tentang minuman keras serta banyaknya waktu luang yang tidak digunakan dengan baik setelah jam pulang sekolah. Hasil pengamatan juga menunjukkan bahwa organisasi yang berada di lingkungan SMK Likupang seperti Osis, Pramuka dan kegiatan ekstrakurikuler lainnya belum berjalan secara optimal, hal ini disebabkan karena pengetahuan manajemen organisasi masih kurang serta motivasi dari siswa-siswa untuk aktif dalam organisasi masih rendah. 
Universitas Negeri Manado sebagai Perguruan Tinggi Negeri yang berada di Sulawesi Utara memerlukan calon mahasiswa yang unggul dan berkualitas untuk dapat masuk menjadi mahasiswa di Universitas Negeri Manado. Berbagai program dari institusi telah dan terus dilakukan dalam menunjang tri dharma perguruan tinggi yaitu Pengajaran, Penelitian dan Pengabdian harus turut berkontribusi dalam pembentukan karakter siswa sebagai generasi muda skaligus sebagai calon mahasiswa yang berkualitas. Universitas Negeri Manado dapat mengambil bagian dengan turut peduli terhadap keadaan yang terjadi pada remaja khususnya siswa saat ini dalam rangka menjauhkan mereka dalam menkomsumsi minuman keras dengan melakukan penyuluhan tentang bahaya dan sanksi hukum penyalahgunaan minuman keras dari dosen-dosen yang berkompoten di bidang hukum serta mambantu sekolah dalam mengoptimalkan organisasi sekolah dalam pembentukan karakter siswa..

\section{KAJIAN LITERATUR}

\section{Penge rtian Minuman Keras}

Minuman keras (disingkat miras), minuman suling, atau spirit adalah minuman beralkohol yang mengandung etanol yang dihasilkan dari penyulingan (yaitu, berkonsentrasi lewat distilasi) ethanol diproduksi dengan cara fermentasi biji-bijian, buah, atau sayuran

Di Indonesia, definisi "minuman keras" dan "minuman beralkohol" tercampur aduk dan cenderung dianggap barang yang sama sehingga juga meliputi minuman fermentasi yang tidak disuling seperti bir, tuak, anggur, dan cider.

Sejak zaman dahulu, minuman keras sudah beredar di Indonesia, tapi bentuknya masih minuman yang tradisional, seperti arak. Pengertian minuman arak di kalangan masyarakat Indonesia memang sudah dipandang negatif. Hal tersebut dikarenakan banyaknya dampak negatif yang terjadi akibat meminum minuman keras.

Alkohollah yang merupakan zat berbahaya dalam tubuh bila dikonsumsi. Jadi, minuman keras itu tidak lain adalah alkohol. Minuman beralkohol adalah minuman yang mengandung zat etanol, zat psikoaktif yang bila dikonsumsi akan mengakibatkan kehilangan kesadaran.

Minuman beralkohol merupakan minuman keras yang termasuk kategori jenis zat narkotika yang mengandung alkohol.

Minuman keras alkohol mengandung etil alkohol yang diperoleh dari hasil fermentasi madu, gula, sari buah, atau umbi-umbian. Lamanya proses fermentasi bergantung pada bahan dan jenis produk minuman keras yang dihasilkan. Kandungan etanol yang dihasilkan 
dalam fermentasi minuman keras beralkohol biasanya berkisar antara sekitar $18 \%$. Umumnya, minuman keras tidak akan awet pada lingkungan dengan kandungan etanol di atas $18 \%$.

Minuman keras beralkohol dengan kandungan etanol yang lebih tinggi dapat dihasilkan melalui proses distilasi terhadap produk yang dihasilkan melalui proses fermentasi. Misalnya, untuk menghasilkan minuman keras alkohol berkadar etanol tinggi, dengan cara mencampur produk hasil fermentasi dengan produk hasil distilasi. Contohnya, port wine dan sherry yang termasuk kelompok fortified wine.

\section{Jenis-Jenis Minuman Keras}

Minuman keras memiliki varian-varian tertentu berdasarkan bahan pembuatannya dan kadar etanol yang dikandungnya. Berikut jenis-jenis minuman keras alkohol dengan kadar etanol yang dimilikinya.

Bir 3-5\%.

Wine $9-18 \%$.

Anggur obat 9-18\%.

Liquor Min. 24

Whisky Min.30.

Brandy Min. 30.

Genever Min.30.

Cognac Min.35.

Gin Min.38.

Rum Min.38.
Arak Min.38.

Vodka Min.40.

Berdasarkan Kepres No. 3 Tahun 1997 tentang Pengawasan dan Pengendalian Minuman Beralkohol, minuman beralkohol dibagi menjadi 3 golongan.

Golongan A: kadar etanol 1-5\% (Bir Bintang dan Green Sands).

Golongan B: Kadar etanol 5-20\% (Anggur Malaga).

Golongan C: Kadar etanol 20-55\% (Brandy dan Whisky).

\section{Dampak Negatif}

Efek negatif minuman keras apabila digunakan berlebihan.

1. Gangguan Mental Organik (GMO)

Gangguan ini akan mengakibatkan perubahan perilaku, seperti bertindak kasar, gampang marah sehingga memiliki masalah dalam lingkungan sekitar. Perubahan fisiologi seperti mata juling, muka merah dan jalan sempoyongan. Perubahan psikologi seperti susah konsentrasi, sering ngelantur dan gampang tersinggung.

2. Merusak Daya Ingat

Kecanduan minuman keras dapat nghambat perkembangan memori dan sel-sel otak.

3. Oedema Otak 
Pembengkakan dan terbendunganya darah di jaringan otak. Sehingga mengakibatkan gangguan koordinasi dalam otak secara normal.

4. Sirosis Hati

Peradangan sel hati secara luas dan kematian sel dalam hati akibat terlalu banyak minum minuman keras.

\section{Gangguan Jantung}

Terlalu banyak minum minuman keras dapat membuat kerja jantung tidak berfungsi dengan baik.

6. Gastrinitis

Radang atau luka pada lambung. Ini biasanya diakibatkan gara2 muntah akibat mninuman keras, karena lambung harus memompa secara paksa keluar zat-zat adiktif yang beracun dalam tubuh.

\section{Paranoid}

Karena kecanduan, kadang2 peminum sering seperti merasa kepala dipukuli atau tidak tenang. Sehingga perilakunya menjadi lebih kasar terhadap orang di sekelilingnya.

\section{Keracunan/Mabuk}

Terlalu banyak minum minuman keras dapat menghilangkan kesadaran dirinya alias udah naik atau ngefly. Biasanya ini yang dibilang "enak" dari minuman keras.

\section{Landasan Hukum tentang Minuman Keras}

- Dalam kitab undang-undang hukum pidana (KUHP) mengatur mengenai masalah penyalahgunaan Minuman Keras (Khamar), alkohol atau tindak pidana minuman keras yang tersebar dalam beberapa pasal, antara lain pasal 300; pasal 492; pasal 536; pasal 537; pasal 538; pasal 539 KUHP. Adapun bunyi pasal-pasal tersebut adalah sebagai berikut[1] :

a. Pasal 300 KUHP :

Dengan hukuman penjara selama-lamanya satu tahun atau denda sebanyak-banyaknya Rp. 4.500,- di hukum :

1. Barang siapa dengan sengaja menjual atau menyuruh minum minuman-minuman yang memabukan kepada seseorang yang telah kelihatan mabuk.

2. Barang siapa dengan sengaja membuat mabuk seseorang anak yang umurnya dibawah 18 tahun.

3. Barang siapa dengan kekerasan atau ancaman kekerasan dengan sengaja memaksa orang akan minum-minuman yang memabukkan

4. Kalau perbuatan itu menyebabkan luka berat pada tubuh, sitersalah dihukum penjara selamalamanya tujuh tahun.

5. Kalau perbuatan itu menyebabkan orang mati, sitersalah dihukum penjara selamalamanya sembilan tahun. 
6. Kalau sitersalah melakukan kejahatan itu dalam jabatan ia dapat dipecat dari pekerjaan itu.

Untuk ketentuaan pidana yang diatur di dalam pasal 300 ayat (3), yakni tindak pidana yang menyebabkan korban itu mati. Pada tindak pidana tersebut, yang dapat meninggal dunia itu ialah :

1. Korban sendiri, yakni orang yang dipaksa untuk meminum minuman yang sifatnya memabukan;

2.Salah seorang dari pelaku, yakni misalnya korban dari moodweer yang dilakukan oleh orang yang dipaksa meminum minuman yang sifatnya memabukan;

3.Orang lain yang sama sekali tidak ada hubungannya dengan tindak pidana yang bersangkutan, yakni misalnya yang telah menjadi korban sebagai akibat perilaku orang yang berada dalam keadaan mabuk.[4]

b. Pasal 492 KUHP

1) Barang siapa yang sedang mabuk, baik ditempat umum merintangi jalan atau mengganggu ketertiban, baik mengancam keamanan orang lain maupun sesutu perbuatan yang harus dijalankan dengan hati-hati benar supaya tidak terjadi bahaya bagi jiwa atau kesehatan orang lain dihukum kurungan selamalamanya enam hari atau denda sebanyakbanyaknya Rp. 375,-
2) Jika pada waktu melakukan pelanggaran itu belum lagi lewat satu tahun sejak ketetapa putusan hukuman yang dahulu bagi si tersalah karena pelanggaran serupa itu juga atau lantaran pelanggaran yang diterangkan dalam pasal 536 maka ia dihukum kurungan selama-lamanya dua minggu.

\section{c. Pasal 536 KUHP :}

1) Barang siapa nyata mabuk ada dijalan umum, dihukum denda sebanyak-banyaknya Rp. 225,-

2) Jika pada waktu melakukan pelanggaran itu belum satu tahun, sejak ketetapan hukum yang dahulu bagi si tersalah lantaran pelanggaran serupa itu juga atau pelanggaran yang ditersangkakan dalam pasal 492, maka hukuman denda itu dapat diganti dengan hukuman kurungan selama-lamanya tiga hari.

3) Kalau pelanggaran itu diulangi untuk kedua kalinya dalam satu tahun sesudah keputusan hukuman yang pertama karena ulangan pelanggaran itu, maka dijatuhkan hukuman kurungan selama-lamanya dua minggu.

4) Kalau pelanggaran itu diulangi untuk ketiga kalinya atau selanjutnya di dalam satu tahun sesudah ketetapan putusan hukuman yang kemudian sekali lantaran ulangan pelanggaran untuk kedua kalinya atau selanjutnya, maka dijatuhkan hukuman kurungan selama-lamanya tiga bulan. 
Supaya dikenakan pasal ini si tersalah harus sedang mabuk dan berada di jalan umum, orang yang berada dalam keadaan mabuk itu tetap tersalah atau tetap dapat diminta pertanggung jawabannya menurut hukum pidana atas perbuatan yang telah ia lakukan. Keadaan mabuk merupakan keadaan yang sebenarnya dari seseorang yang berada dalam keadaan seperti itu, sehingga di dalam surat dakwaannya, jaksa cukup memakai kata-kata dalam keadaan mabuk bagi terdakwa, yang didakwa telah melakukan tindak pidana seperti yang dimaksudkan di dalam ketentuan pidana yang diatur pasal 536 KUHP. Keadaan yang nyata bahwa seseorang itu berada dalam keadaan mabuk hanya dapat dibuktikan dengan menunjukkan perbuatan-perbuatan yang telah dilakukan oleh terdakwa, dan dengan menunjukkan keadaan-keadaan terdakwa pada waktu ia berada di atas jalan raya[5]. Jika keadaan mabuk berada di dalam rumah, maka tidak dikenakan pasal ini.

d. Pasal 537 KUHP :

"Barang siapa menjual atau memberikan minuman keras atau arak kepada anggota Angkatan Bersenjata di bawah pangkat letnan atau kepada istrinya, anak atau pelayan, diancam dengan pidana kurungan paling lama tiga minggu atau pidana denda paling tinggi seribu lima ratus rupiah.”
Yang diancam dengan hukuman pasal ini ialah orang yang menjual atau memberi minuman keras atau tuak diluar kantin tentara kepada seorang prajurit militer dengan pangkat letnan kebawah, atau kepada istri, anak atau bujangnya perajurit itu.[6]

e. Pasal 538 KUHP :

"Penjual atau wakilnya yang menjual minuman keras yang dalam menjalankan pekerjaan memberikan atau menjual minuman keras atau arak kepada seorang anak dibawah umur enam belas tahun, diancam dengan pidana kurungan paling lama tiga minggu atau pidana denda paling tinggi empat ribu lima ratus rupiah." Yang dapat dihukum menurut pasal ini adalah penjual minuman keras yang memberikan minuman keras kepada anak dibawah umur. Untuk dapat menyatakan seseorang terdakwa terbukti mempunyai kesengajaan dalam melakukan pelanggaran seperti yang dimaksudkan di dalam ketentuan pidana yang di atur pasal 538 KUHP, hakim harus dapat membuktikan tentang :

1. Adanya kehendak atau maksud terdakwa untuk menyajikan atau menjual minuman keras 2. Adanya pengetahuan pada terdakwa bahwa yang ia sajikan atau jual itu ialah minuman keras atau tuak

3. Adanya pengetahuan pada terdakwa bahwa minuman keras atau tuak itu telah ia 
sajikan atau ia jual kepada seorang anak di bawah usia enam belas tahun.[7]

Yang dimaksud penjual minuman keras bukan hanya orang-orang yang mengkhususkan diri menjual minuman keras, melainkan juga orang-orang yang di samping penjual barangbarang yang lain juga menjual minuman keras seperti pemilik toko, pengusaha rumah makan atau kedai dan lain-lainnya. Adapun yang dapat disebut sebagai pengganti dari penjual minuman keras tersebut, antara lain istrinya, anaknya, pegawainya dan lain-lain.

\section{f. Pasal 539 KUHP :}

"Barang siapa pada kesempatan diadakan pesta keramaian untuk umum atau pertunjukan rakyat atau diselenggarakan arak-arakan untuk umum, menyediakan secara cuma-cuma minuman keras atau menjanjikan sebagai hadiah, diancam dengan pidana kurungan paling lama dua belas hari atau pidana denda paling tinggi tiga ratus tujuh puluh lima rupiah.

\section{METODE PENGABDIAN}

Metode yang digunakan adalah :

1.Penyuluhan dengan kegiatan

a.Ceramah berbantuan multi media

b.Diskusi interaktiff

c.Demonstrasi

d.Pemutaran Film
e.Pembagian poster-poster antimiras untuk ditempel

f.Pembagian selebaran antimiras

2.Optimalisasi kegiatan organisasi siswa melalui perancangan kegiatan bersama guru dan sebagian siswa.

3.Pembentukan wadah /organisasi siswa anti miras dan perancangan pembentukan kelompok-kelompok belajar dan kegiatan diluar sekolah

Adapun tahapan kegiatan dalam Pengabdian ini yaitu

1.Observasi awal

2.Pembuatan Rencana kegiatan

3.Implementasi Rencana kegiatan baik bagi guru dan siswa

4.Evaluasi program

Pada tahap observasi awal guru dan perangkat sekolah termasuk pimpinan, pegawai dan siswa SMK Likupang diwawancarai tentang situasi/keadaan sekolah dan karakteristik serta perilaku siswa serta permasalahan yang dihadapi. berdasarkan observasi awal kemudian dibuat perencanaannya dan pada tahap implementasi rencana langsung di sekolah mitra yaitu SMK Likupang. Pada tahap evaluasi program Pengabdian untuk melihat tingkat keberhasilan pelaksanaan kegiatan dan tindak lanjutnya. 


\section{HASIL DAN PEMBAHASAN}

Pelaksanaan kegiatan pengabdian kepada masyarakat yang berjudul Penyuluhan Berbasis Multimedia Tentang Masalah Penyalagunaan Minuman Keras Dan Optimalisasi Kegiatan Organisasi Siswa Smk Likupang ini melalui beberapa tahapan sebagai berikut :

a. Pembukaan

Pembukaan kegiatan pengabdian ini dilaksanakan di Aula SMK Likupang yang di hadiri oleh 90 orang siswa dan 20 orang guru yang diawali dengan doa buka, sambutan mewakili pihak sekolah, sambutan oleh pihak unima.

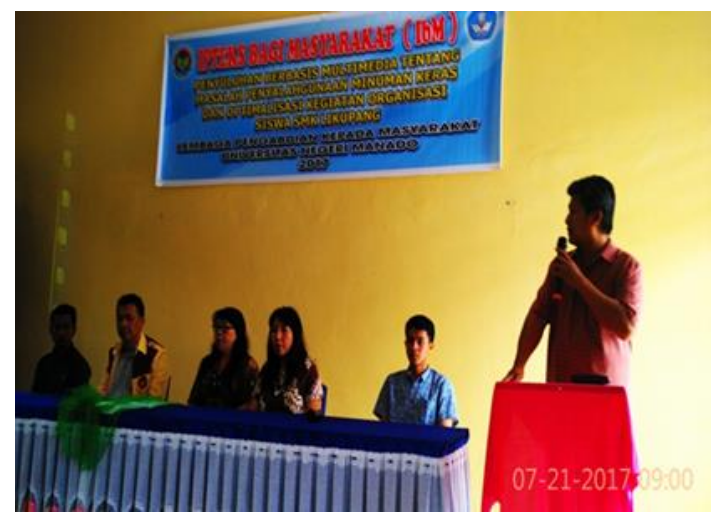

Gambar 1. Ucapan selamat datang sekaligus doa buka

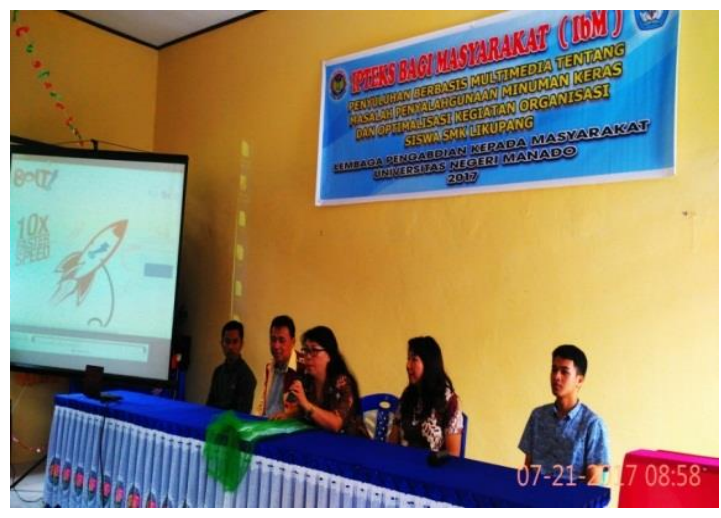

Gambar 2. Sambutan dari pimpinan sekolah

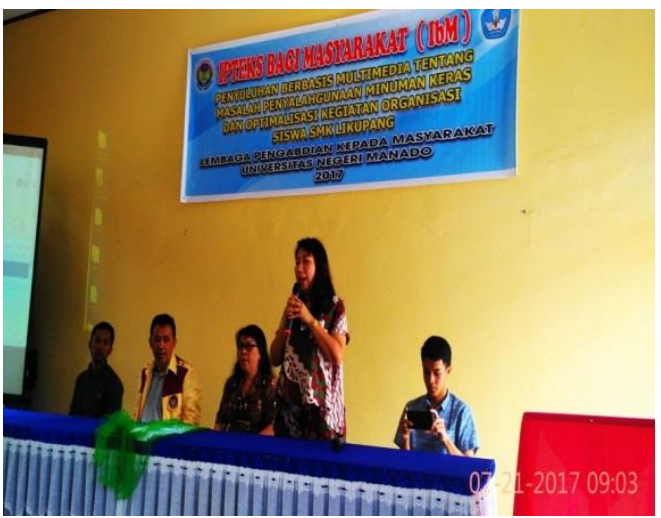

Gambar 3. Sambutan Tim Unima

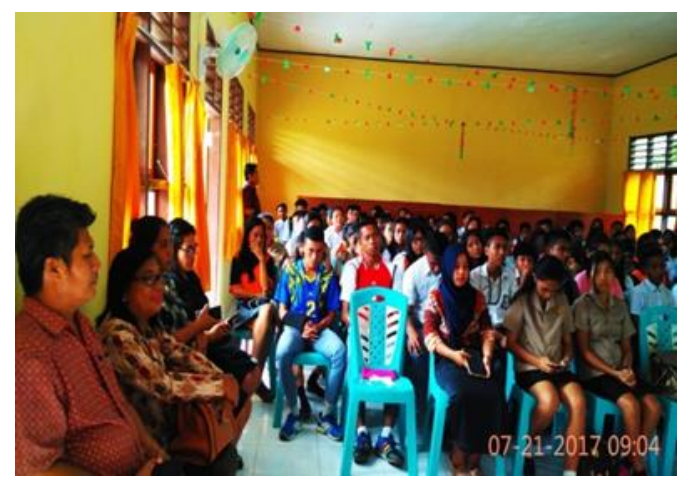

Gambar 4. Peserta Pelatihan Guru dan siswa 
b. Pelaksanaan pelatihan

Tahapan kegiatan ini dimulai dengan perkenalan dilanjutkan dengan pemberian materi penyuluhan berbasis multimedia dengan pemutaran beberapa film sesuai dengan topik kegiatan ini. Setelah selesai penyuluhan dilakukan diskusi atau tanya jawab dan kemudian sesuai dengan tujuan kegiatan diadakan kegiatan optimalisasi kegiatan Organisasi siswa SMK Likupang.
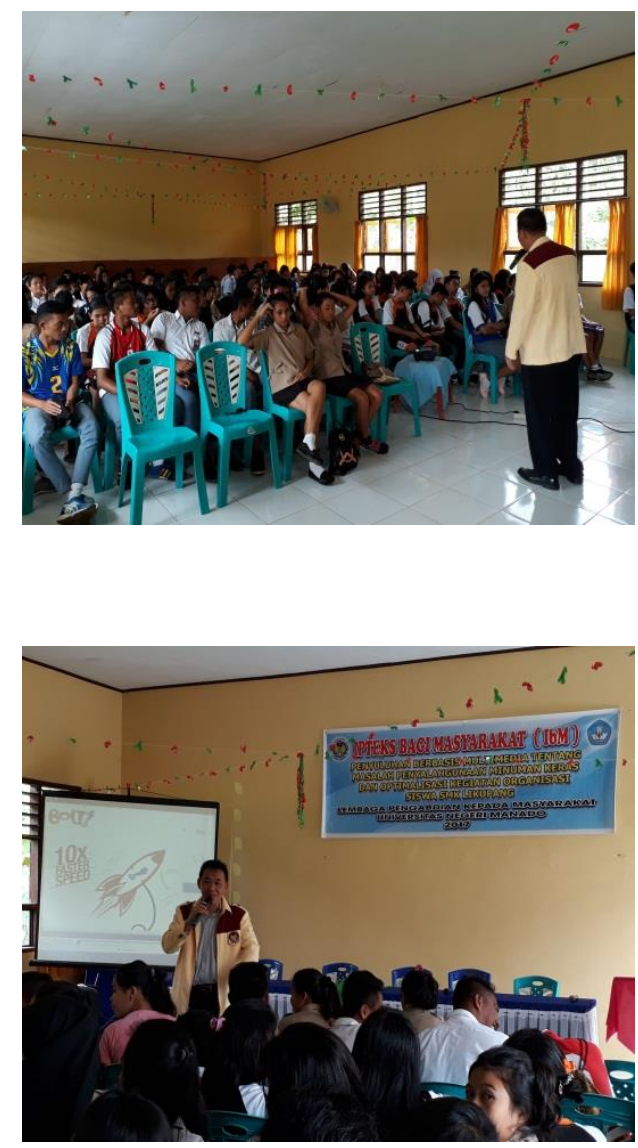

Gambar 5. Memberikan materi
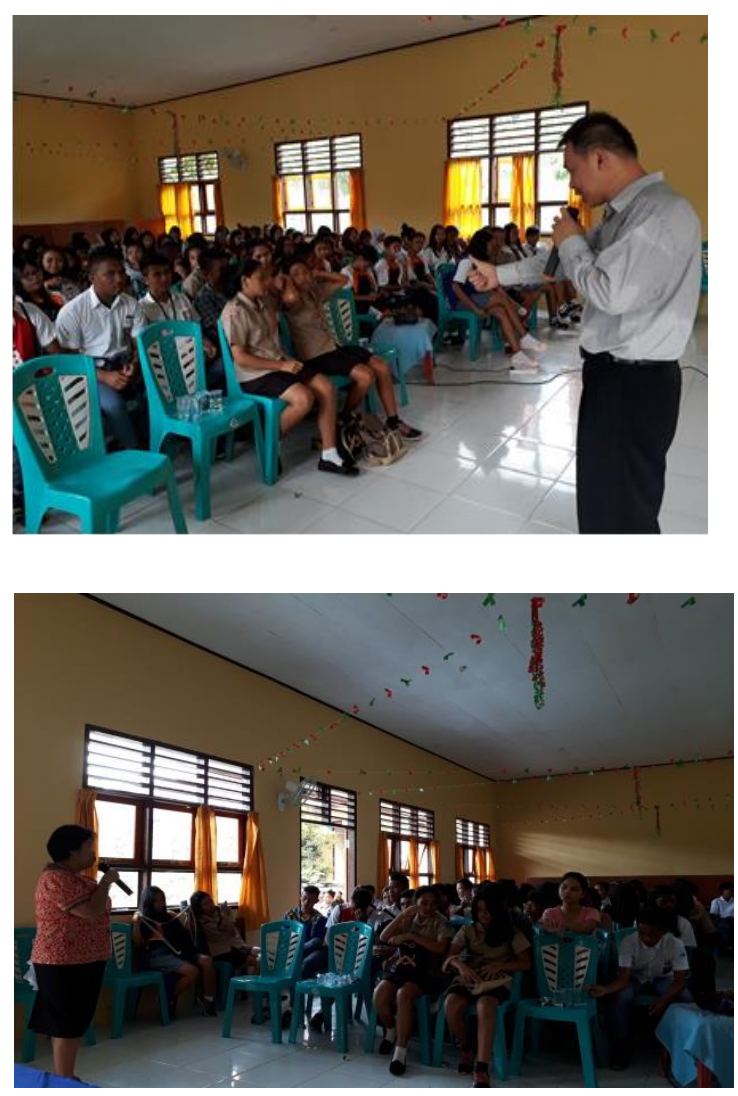

Gambar 6. Optimalisasi kegiatan organisasi sekolah

c. Penutupan

Sebagai acara penutup yaitu santap kasih bersama.

\section{KESIMPULAN DAN SARAN}

\section{Kesimpulan}

Berdasarkan hasil kegiatan dan tindakan yang sudah dilaksanakan di lokasi kegiatan maka dapat disimpulkan beberapa hal 
- Kegiatan pengabdian kepada masyarakat ini telah terlaksana dengan baik.

- Pihak sekolah telah menerima tim pengabdian kepada masyarakat dari Unima dengan baik

- Siswa-siswa SMK Likupang yang hadir pada saat kegiatan dilaksanakan berjumlah 90 orang

- Siswa-siswi SMK Likupang sangat antusias mengikuti kegiatan ini sampai dengan selesai.

- Siswa-siswa SMK Likupang telah memiliki pengetahuan tentang minuman keras bahaya dan sanksi jika mengkonsumsi minuman keras

- Optimalisasi kegiatan organisasi SMK Likupang dan mereka akan membentuk organisasi anti miras

\section{Saran}

- Perlu diadakan lagi di SMK Likupang penyuluhan lanjutan tentang penyalagunaan Narkoba

- Harus ada tindak lanjut terhadap kegiatan pengabdian kepada masyarakat yang telah dilaksanakan oleh Universitas negeri manado melalui kerja sama dengan mitra dalam hal ini dengan SMK Likupang

\section{KEPUSTAKAAN}

HasanBasri.2006,RemajaBerkualitas,Problemati k Remaja dan Solusinya.Yogyakarta: Pustaka Belajar

Kartini Kartono. 2003 Psikologi Remaja. Bandung: Mandar Manju
Sukardi. 2000,Bimbingan dan Penyuluhan di Sekolah. Jakarta: Bina Aksara

Ulfah, D. M., 2005, Skripsi Tentang FaktorFaktor Penggunaan Minuman Keras Di Kalangan Remaja Di Desa Losari Kecamatan Rembang Kabupaten Purbalingga.

http://digilib.unnes.ac.id/gsdl/collect/wrd pdfe/index/ assoc/HASH01bd/17e47c4a.dir/doc.

Zulvikar, 2008, Minuman-Minuman Keras ,http://zulv1ck4r.wordpress.com /2008/12/30/minum- minuman-keras/..

Z, Fikri., 2007. Keputusan Presiden Nomor: 3 Tahun 1997 (3/1997) Tentang: Pengawasan Dan Pengendalian Minuman Berakohol, http//zfikri.wordpress.com/2007/06/ 02/keppres-no-31997pengawasandan-pengendalian-minumanberalkohol/. 